\title{
NOTES ON AMERICAN NEMESTRINIDAE
}

\author{
BY J. BEQUAER'T \\ Department of Tropical Medicine, \\ Harvard University Medical School
}

Most of the following notes have been in manuscript for a number of years, pending their inclusion in a revision of the American representatives of this family. The recent discovery of some of these flies in Yucatan prompts their publication in the present form.

\section{Subfamily Nemestrininae}

The subfamily Nemestrininae should, in my opinion, comprise all nemestrinids with an elongate, slender, hard proboscis, the labium usually provided with narrow labella. All the North and Central American species belong to one genus, Neorhynchocephalus.

\section{Neorhynchocephalus Lichtwardt}

Neorhynchocephalus Lichtwardt, 1909 (July), Deutsch. Ent. Zeitschr., p. 512 (based upon two species: Rhynchocephalus sackeni Williston, 1880 , and $R$. volaticus Williston, 1883) ; 1910, Loc. cit., p. 592.

Rhynchocephalus subgenus Nemestrinopsis Cockerell, 1910 (October), Bull. Amer. Mus. Nat. Hist., XXVIII, p. 285 (type by original designation: Rhynchocephalus volaticus Williston, 1883).

This genus, which is exclusively American, may be defined as follows:

Medium-sized flies, densely pilose, often with narrow hair-bands on the abdomen; the integument black, dark brown, or reddish yellow. Head broad and short, flattened 
hemispherical. Face flattened or slightly concave. Frons flattened; linear or more or less narrowed beneath the ocellar triangle in the male (the eyes almost holoptic in certain species) ; very broad in the female, often occupying about one-third of the width of the head. Eyes bare. Proboscis elongate, stylet-like, slender, usually directed downward and backward, more rarely slanting forward; terminal labella long and slender, slightly flattened. Palpi short, very slender. Antennæ short; the two basal segments subequal, transverse; the third subcircular, flattened with a terminal, three-segmented, bare arista. Ovipositor of female long, sabre-shaped, composed of two slender, curved valves. Wing: alula broad; apical half never with a network of cross-veinlets; branches of third and fourth longitudinal veins long, running parallel with the hind margin; third and fourth veins never coalescing before the margin; first and second submarginal cells separated by a crossvein (Cockerell's outer radio-medial) ; costa as a rule enclosing the hind margin of the wing completely and usually reached by the fifth longitudinal (or apical portion of diagonal vein), which thus divides the third and fifth posterior cells; base of fourth posterior cell removed from the anal cell and situated at or slightly beyond the lower basal corner of the discal cell; anterior cross-vein absent, the fourth longitudinal vein usually reaching the third some distance basad of the latter's branching.

Genotype. by present designation: Rhynchocephalus volaticus Williston, 1883.

Lichtwardt (1907, Zeitschr. Syst. Hym. Dipt., VII, p. 451) first pointed out that, in the genotype of Rhynchocephalus Fischer (R. tauscheri Fischer), the upper branch of the fifth longitudinal vein does not reach the hind margin of the wing. He later (1909) proposed a new genus, Neorhynchocephalus, for the Nearctic $R$. sackeni and $R$. volaticus, in which the hind margin is thickened into a vein, reached by the diagonal vein. Neorhynchocephalus was more fully characterized by Lichtwardt in 1910. ${ }^{1}$ About the same time and quite independently from Lichtwardt, Cockerell also noticed that the diagonal vein extends to the hind margin in $R$. volaticus, while such is not the case in typical Rhynchocephalus. He therefore placed $R$. volaticus in a 
new subgenus Nemestrinopsis. It would seem, however, that he wished to retain $R$. sackeni Williston and $R$. subnitens Cockerell in Rhynchocephalus, proper, although this is not clear from his paper.

The distinction between Rhynchocephalus and Neorhynchocephalus is entirely based upon two peculiarities of the venation. The first of these, viz., the development of the costa along the hind margin and its connection with the diagonal vein, is probably too slight and variable to be of generic value. At any rate, in some of the specimens of $N$. sackeni which I have examined, certain stretches of the hind margin are not visibly thickened into a vein, and the margin is not fully reached by the diagonal vein, the third and fifth posterior cells being incompletely divided. The second feature, viz., the contraction of the base of the fourth posterior cell, appears to be more reliable: it is present in 40 specimens of Neorhynchocephalus, belonging to the four known species. As a rule, the cell is briefly stalked at the base; but sometimes it is narrowly sessile on the second basal cell. I have seen only one specimen in which it was narrowly sessile on the anal cell, but even this condition is very different from that of Rhynchocephalus tauscheri Fischer, in which the base of the fourth posterior cell touches the anal cell over a long stretch, its lower margin running nearly parallel with the lower margin of the discal cell.

Contrary to Lichtwardt's statement, the shape of the frons in the male is not of generic significance. He writes that in Neorhynchocephalus the eyes touch each other on the vertex in the male; while the male of Rhynchocephalus has the eyes distinctly separated by the ocelli. In fact, the males of both genera have the eyes separated on the vertex itself by the ocellar triangle; below this the frons may be more or less narrowed. In N. volaticus and N. sackeni the frons is very much narrowed and linear, so that the eyes seem to touch each other. In two males of $N$. vitripennis (Wiedemann) the frons is moderately narrowed, the eyes being distinctly separated.

1 The Zoological Record lists Neorhynchocephalus as dating from this 1910 paper; but the genus was validly established a year before. 
Quite possibly Neorhynchocephalus should not be given generic rank, and rather be regarded as at most of subgeneric value. While it is not represented in the old World, so far as we know, it does not contain all the New World species. Lichtwardt has described Rhynchocephalus mendozanus (1910, Deutsch. Ent. Zeitschr., p. 594; 우 o ), from Argentina, which he says has the venation of $R$. tauscheri, except "dass sich Cubitus und Media in einem Schnittpunkte trennen."

The four known species of Neorhynchocephalus may be separated as follows:

1. Two branches of fourth longitudinal vein united before the costa, the second posterior cell closed and with a long apical stalk. Black, with dense, rather short, pale yellowish pile; the abdomen not distinctly banded nor spotted. Length, 6 to $10 \mathrm{~mm}$.....N. sackeni (Williston).

Two branches of fourth longitudinal vein ending freely in the costa, some distance from each other, the second posterior cell not stalked at the apex

2. North and Central American species. Tibiæ and tarsi darker than the femora, especially those of the hind legs. Body covered with pale yellowish pile; the abdominal tergites with more or less distinct, white, apical fringes, and with small tufts of black hair on the sides; tergites often spotted with yellowish red. Frons linear in the male, the eyes nearly touching over some length below the ocellar triangle. Length, 8.5 to $14 \mathrm{~mm}$.

$N$. volaticus (Williston).

South American species. Legs uniformly pale colored, dirty yellow to reddish-yellow. Abdominal tergites without distinct, white, apical fringes, but on the sides with more prominent tufts of hair, which are partly black ..3.

3. Head, thorax and legs densely covered with long bright sulphur-yellow pile. Wings distinctly infuscated at the extreme base. Length, 8 to $10 \mathrm{~mm}$. (Male unknown to $\mathrm{me}$ ) N. sulphureus (Wiedemann). 
Head, thorax and legs covered with pale yellowish pile. Wings subhyaline throughout, at most slightly yellowish at the base. Male: frons narrowed beneath the ocelli, but the eyes separated by about half the basal width of the ocellar triangle. Length, 8 to $11 \mathrm{~mm}$.

N. vitripennis (Wiedemann).

\section{Neorhynchocephalus volaticus (Williston)}

Rhynchocephalus volaticus Williston, 1883, Canad. Entom., XV, pp. 70 and 71, fig. 4 ( 9 ; Florida) ; 1886, Trans. Amer. Ent. Soc., XIII, p. 293 ( q ) ; 1888, "Synopsis North American Diptera," p. 33, fig. C. W. Johnson, 1895, Proc. Ac. Nat. Sci. Phila., XLVII, p. 325. Williston, 1901, "Biologia Centr.-Amer.," Dipt., I, p. 269. Aldrich, 1905, "Cat. North Amer. Dipt.," p. 219. Cockerell, 1908, Trans. Amer. Ent. Soc., XXXIV, p. 250. Williston, 1908, "Manual of North American Diptera," 3d Ed., p. 186, fig. 68. Kertész, 1909, "Cat. Dipt.," IV, p. 30 .

Neorhynchocephalus volaticus Lichtwardt, 1909, Deutsch. Ent. Zeitschr., p. 512; 1910, Loc. cit., p. 593, fig. 2. C. W. Johnson, 1913, Bull. Amer. Mus. Nat. Hist., XXXII, p. 54. F. M. Hull, 1923, Ent. News, XXXIV, p. 275 ( $\left.\begin{array}{ll}\text { o } & 0\end{array}\right)$.

Rhynchocephalus (Nemestrinopsis) volaticus, Cockerell, 1910, Bull. Amer. Mus. Nat. Hist., XXVIII, pp. 285 and 286.

Rhynchocephalus species, Osten Sacken, 1886, "Biologia Centr.-Amer.," Dipt., I, p. 73 ( ( ) .

SPECIMEns Examined.-Florida: one female (holotype) and two other females, without more definite locality (Riley Coll.-U. S. Nat. Mus.) ; St. Augustine, one male (C. W. Johnson Coll.); Georgiana, one female (Whitfeld Coll.U. S. Nat. Mus.). Texas: one female and one male, without more definite locality; Cotula, one female, May 12, 1906 (J. C. Crawford Coll.-U. S. Nat. Mus.) ; two males, labelled "Neucest" (Marlatt Coll._U. S. Nat. Mus.) ; Ray- 
mondville, one female and one male (F. M. Hull Coll.). Mississippi: Agricultural College near Starkville, several females and males (E. K. Dickey, W. E. Anderson, and F. M. Hull Coll.). Kansas : Bourbon Co., $800 \mathrm{ft}$., one female (R. H. Beamer Coll.) ; Sumner Co., 1189 ft., one female (R. H. Beamer Coll.) ; Lawrence, one female (C. H. Curran Coll.) ; Douglas Co., one male (W. J. Brown Coll.). Mexico: Presidio River, Villa Union, Sinaloa, one female (A. Kusche Coll. U. S. Nat. Mus.3; Venodio [? Fenochio, Sinaloa], one female (A. Kusche Coll.-U. S. Nat. Mus.) ; State of Colima, one female (L. Conradt Coll.-U. S. Nat. Mus.) ; Mexico City, one female (Juan Muller Coll.-_U. S. Nat. Mus.) ; Matamoros, Morelos, one female (W. L. Tower Coll.) ; Altamira Farms, four males (M. E. Hoag Coll.-Ac. N. Sci. Phila.). Yucatan: Chichen Itza, three females, and six males, taken in the dry forest, from June 6 to 10,1929 ; the species is evidently common in this locality, although difficult to find and to collect; it is on the wing during the warmest and sunniest hours of the day, when it hovers in the bushes, some 2 to $10 \mathrm{ft}$. above the ground, poising on a spot for many minutes, while producing a characteristic, highpitched noise; after a while it may rest on the tip of a dry branch.

There are also reliable, published records of $N$. volaticus from Kingsville, Texas; West Point, Mississippi ; Chilpancingo, Guerrero; Mazatlan, Sinaloa; Vera Cruz, Mexico; and San Geronimo, Guatemala.

\section{Neorhynchocephalus sackeni (Williston)}

Rhynchocephalus sackeni Williston, 1880, Trans. Conn. Ac. Sci., IV, 4, p. 243, fig. ( 9 ; Olympia, Washington State) ; 1883, Canad. Entom., XV, pp. 70 and 71 ( $)$ ) ; 1894, Ent. News, V, p. 47. Snow, 1903, Kansas Univ. Sci. Bull., II, 5, p. 214. Hine, 1904, Canad. Entom., XXXVI, pp. 86 and 90. Aldrich, 1905, "Cat. North Amer. Dipt.," p. 219. Cockerell, 1908, Trans. Amer. Ent. Soc., XXXIV, p. 249, Pl. XVI, figs. 1 and 3. Kertész, 1909, “Cat. Dipt.," IV, p. 30. Cockerell, 1910, Bull. Amer. Mus. Nat. Hist., XXVIII, p. 286. Schaeffer, 1912, Jl. 
New York Ent. Soc., XX, p. 296. Cole and Lovett, 1921, Proc. Calif. Ac. Sci., (4) XI, p. 239.

Neorhynchocephalus sackeni Lichtwardt, 1909, Deutsch. Ent. Zeitschr., p. 512; 1910, Loc. cit., p. 593 (웅).

Rhynchocephalus clausus F. Brauer, 1883, "Offenes Schreiben als Antwort auf H. B. Osten-Sacken's 'Critical ReView," Wien, p. 8. Not of Osten Sacken, 1877.

Rhynchocephalus subnitens Cockerell, 1908, Trans. Amer. Ent. Soc., XXXIV, p. 250 ( $q$; Clark Co., Kansas) ; 1910, Bull. Amer. Mus. Nat. Hist., XXVIII, p. 286. Schaeffer, 1912, Jl. New York Ent. Soc., XX, p. 296.

Neorhynchocephalus subnitens Lichtwardt, 1910, Deutsch. Ent. Zeitschr., p. 593.

SPecimens Examined.-Southern Illinois, one female (C. Robertson Coll.-U. S. Nat. Mus.). Kansas: Clark Co., one female (F. H. Snow Coll.). New Mexico: West Canyon Camp, Koehler, one female and one male (W. R. Walton Coll.-U. S. Nat. Mus.). Arizona: Huachuca Mountains one male (C. Schaeffer Coll.). Colorado: one female and seven males, without more definite locality (U. S. Nat. Mus. and Zool. Inst. Halle a. S.) ; Fort Collins, one male (in Coll. Johnson). Utah: Mill Creek, one male (L. P. Rockwood Coll.) ; Salt Lake City, one female (E. C. Titus Coll.- M. C. Z. Cambridge). Idaho: Grangeville, one female (J. M. Aldrich Coll.) ; Whitebird, one male (J. M. Aldrich Coll.). California: Goose Lake, Medoc Co., one male (Holleman Coll.-U. S. Nat. Mus.). Oregon: Mt. Angel, one female and three males (F. Epper Coll.-U. S. Nat. Mus.) ; Forest Grove, one female (M. C. Lane Coll.) ; Lewisburg, one female (J. C. Chamberlin Coll.). Washington State: one female and one male, without more definite locality $(H . K$. Morrison Coll.-U. S. Nat. Mus.) ; Yakima River, two females (M. C. Z. Cambridge) ; Rock Lake, one female (U. S. Nat. Mus.). British Columbia: Vernon, one male (J. S. Hine Coll.).

There are reliable, published records of $N$. sackeni from Morton Co., Kansas; Colorado Springs, Colorado; Mary's Peak, Oregon; Corvallis, Oregon; and Union Co., Oregon. 
Professor Cockerell informs me that two females and one male have been taken at Boulder, Colorado.

After examining a large number of Neorhynchocephalus, I am unable to regard any of the characters given for $s u b$ nitens as of specific or even varietal value. Cockerell described subnitens as follows: "Smaller than $R$. sackeni Will.; length of wing just over $8 \mathrm{~mm}$. (over 91/2 in sackeni) ; pubescence paler, with a sort of greenish gray tint; abdomen less hairy, the bases of segments 2-4 broadly exposed, shining black; ovipositor shorter, with a stronger, more even curvature; eyes apparently lighter and redder; ultimate branches of cubitus (bounding second posterior cell of Williston) uniting a very short distance before margin of wing (a considerable distance in sackeni)." The difference in the venation especially is unimportant, considering the variability exhibited by most species of Nemestrinidae. In the series of $N$. sackeni which I have studied, hardly two specimens are alike in this respect and often the right wing differs considerably from the left. For instance, the third submarginal cell may be petiolate at the base or broadly or narrowly connected with the first submarginal. In one female, from Salt Lake City, the left wing is fairly normal, but in the right wing the third submarginal cell is subdivided at about its basal quarter by a supplementary cross-vein. A somewhat similar abnormal division of the third submarginal cell in one wing is present in a female from Grangeville, Idaho, in a female from Forest Grove, Oregon, and in a male from Colorado; but the crossvein is placed at a varying distance from the tip of the cell. A male from Colorado, in V. v. Röder's collection (Zoological Institute of the University at Halle a. S.), is even more aberrant: while the right wing is normal, in the left wing both the second and third submarginal cells are subdivided by cross-veins, placed a short distance from each other near the middle of the cells; in addition this left wing has a supplementary cross-vein about the middle of the fifth posterior cell, uniting the lower border of the fourth posterior cell with the hind margin. Cockerell also has figured the closed third submarginal cell of the right wing of a male from Colorado. The length of the apical stalk connecting the closed second posterior cell with the margin is very variable and 
often different in both wings; in one case the cell being closed at the margin in the left wing and very short-petiolate in the right; at the base this cell may either touch the fifth posterior cell or be removed some distance above it. The fourth posterior cell is either stalked at the base, or sessile, or narrowly connected with the second basal cell. The anal cell is as a rule open on the hind margin; but in one male from the Huachuca Mountains, Arizona, it is distinctly closed. I may also add that in a letter, dated November 2, 1929, Professor Cockerell has expressed doubts as to the validity of his $R$. subnitens. He now thinks it may have been only a variation.

\section{Neorhynchocephalus sulphureus (Wiedemann)}

Nemestrina sulphurea Wiedemann, 1830, “Aussereurop. Zweifl. Insekt.," II, p. 631 (no sex given; Minas Geraes, Brazil). Hunter, 1901, Trans. Amer. Ent. Soc., XXVII, p. 149.

Nemestrinus sulphureus Kertész, 1909, “Cat. Dipt.,” IV, p. 25.

Neorhynchocephalus sulphureus Lichtwardt, 1910, Deutsch. Ent. Zeitschr., p. 594 ( ㅇ o o ).

SPECIMENS Examined.-Two females from northern Argentina: Mistol Paso near Icano, Chaco de Santiago del Estero (E. R. Wagner-Paris Museum).

Lichtwardt saw Wiedemann's types in the Vienna Museum and he says that they are male and female. $\mathrm{He}$ also studied three specimens of which he does not give the sex and the locality, in the Berlin Museum, and a female from Asuncion, Paraguay, in the Budapest Museum.

The two specimens from Argentina, though otherwise very similar, differ considerably in size; in one the wing is $8 \mathrm{~mm}$. long; in the other $11 \mathrm{~mm}$. The fourth posterior cell is short-stalked at the base in the larger one and very longstalked in the smaller one.

\section{Neorhynchocephalus vitripennis (Wiedemann)}

Nemestrina vitripennis Wiedemann, 1830, "Aussereurop. Zweifl. Insekt.," II, p. 631 ( $q$; Brazil). 
Prosœca vitripennis Schiner, 1868, "Novara Reise," Zool., II, Abt. vol. B, Dipt., p. 112. Kertész, 1909, “Cat. Dipt.," IV, p. 29.

Nemestrina vitreipennis Hunter, 1901, Trans. Amer. Ent. Soc., XXVII, p. 149.

Neorhynchocephalus vitripennis Lichtwardt, 1910, Deutsch. Ent. Zeitschr., p. 594 ( \& ).

Specimens Examined.-Two males. One, merely labelled "Bras.," in V. v. Röder's collection at the Zoological Institute of the University of Halle a. S., is a very old faded specimen, on a short pin, and may have been one of Wiedemann's cotypes. The other is labelled "Chapada," a locality in the southern part of the State of Matto Grosso, Brazil. This appears to be the first definite locality for the species. Lichtwardt only saw Wiedemann's cotypes at the Berlin and Vienna Museums.

Both males I have seen agree in having a well-developed, though narrowed frons below the ocellar triangles; their venation is practically identical. The specimen from Chapada is the larger, its wing being $10.5 \mathrm{~mm}$. long; that of the other specimen measures $8.5 \mathrm{~mm}$.

\section{Subfamily Hirmoneurinae}

The Hirmoneurinae should contain all nemestrinids with a well-developed, but short and broad proboscis, the labium ending in large, fleshy labella. The alula of the wing is always broad and the ovipositor of the female is telescopeshaped, consisting of several narrow segments capable of retraction within one another. In North America, this subfamily is represented by two genera, Hirmoneura Meigen and Hyrmophlaeba Rondani.

\section{Hyrmophlaeba brevirostris (Macquart)}

Hirmoneura brevirostris Macquart, 1845, Mém. Soc. Sci. Lille, (1844), p. 233, Pl. XX, figs. 1-1a; 1846, "Dipt. Exot.," Suppl. 1, p. 101, Pl. XX, figs. 1 and $1 a$ ( $\hat{o}$; 
Merida). Osten Sacken, 1877, Bull. U. S. Geol. Geogr. Surv. Terr., III, p. 224; 1878, Smithson. Miscell. Coll., No. 270 , p. 85 . Williston, 1883 , Canad. Entom., XV, p. 70. Aldrich, 1905, “Cat. North Amer. Dipt."” p. 218. Cockerell, 1908, Trans. Amer. Ent. Soc., XXXIV, pp. 251 and 252, Pl. XVI, fig. 2; 1910, Bull. Amer. Mus. Nat. Hist., XXVIII, p. 286.

Hermoneura brevirostris Kertész, 1909, "Cat. Dipt.," IV, p. 25.

Hyrmophlaeba brevirostris Rondani, 1863, Arch. per la Zoologia, Modena, III, 1, p. 51. Lichtwardt, 1910, Deutsch. Ent. Zeitschr., pp. 580 and 591. J. Bequaert, 1920, Jl. New York Ent. Soc., XXVII, (1919), p. 306.

This species, originally described from the State of $\mathrm{Yu}$ catan, has been reported from Mexico by Lichtwardt. I have seen two specimens from Guatemala: El Rancho, one female (J. S. Hine Coll.), and Gualan (in the eastern part), one male (C. C. Dean Coll.-U. S. Nat. Mus.) .

Since no adequate description of this insect has ever been given, the following notes may help to recognize it.

Female.-Integument of the body uniformly black, entirely covered with ashy gray pruinosity. Antennæ dark brown, the basal segments paler, the arista black. Proboscis and legs pale reddish-yellow, the tibiae dirty white. Body moderately hairy all over. Ocellar triangle and upper part of face with black pilosity; lower part of face and outer orbits with white hairs; two basal segments of antennae with very long and dense, spreading, black hairs, forming fringes above and below. Thorax densely covered with rather long, pure white hairs. Abdomen: first tergite with similar long white pilosity; the succeeding tergites evidently rubbed off in the specimen seen, since they bear only sparse, black and gray hairs, forming small tufts on the sides; sternites covered with silvery white pile. Legs with white hairs, mixed with a few black hairs on tibiæ and tarsi. Head large, hemispherical in profile, about as broad as high, slightly wider than the thorax. Frons extremely narrow, less than one-quarter the width of an eye at its broadest point (just above the antennae); inner orbits diverging 
both in the upper and lower portion, the frons being narrowest about midway between vertex and antennae, where the eyes are barely separated. Ocellar protuberance flattened, forming a much lengthened triangle, not distinctly separated by a groove from the inner orbits. Anterior ocellus about twice as far from the posterior ocelli as these are apart. Eyes very densely covered with long, gray pile. Antennae small, crowded together between the inner orbits; basal segment much longer than the second; third segment flattened, pear-shaped, a little larger than the second. Arista about the length of the combined second and third antennal segments. Body slender and narrow. Dorsum of thorax about as broad as long, the transverse suture distinctly marked on the sides, broadly interrupted in the middle. Scutellum semi-oval, cushion-shaped, with distinctly swollen posterior margin separated from the remainder of the scutellum by a slight groove. Abdomen elongate, oval, ending in an ovipositor composed of several gradually narrowed segments, capable of being telescoped into one another. Legs slender, the femora not swollen. Wing long and slender, slightly over three times as long as wide, a little shorter than the body and much longer than the abdomen; entirely hyaline. Costa distinctly developed along the entire hind margin of the wing and reached by the diagonal vein. The cross-vein separating the first and second submarginal cells reaches the third longitudinal beyond its branching. Three submarginal cells; the third briefly truncate at the base and closed at the apex, which is connected by a long stalk with the costa; the two branches of the third longitudinal vein fused over more than their apical quarter. Anal cell broadly open.

Length (to apex of tergite 4), $10.5 \mathrm{~mm}$.; length of wing, $10 \mathrm{~mm}$.; width of wing, $2.5 \mathrm{~mm}$.

Male.-Differs little from the female, except in the usual sexual peculiarities. Eyes densely pilose, holoptic. In the specimen I have seen, the color of integument and pilosity and the venation of the wing were the same as in the female. The pilosity was, however, much better preserved, the entire abdomen being clothed, like the rest of the body, with long, whitish-gray hairs. 

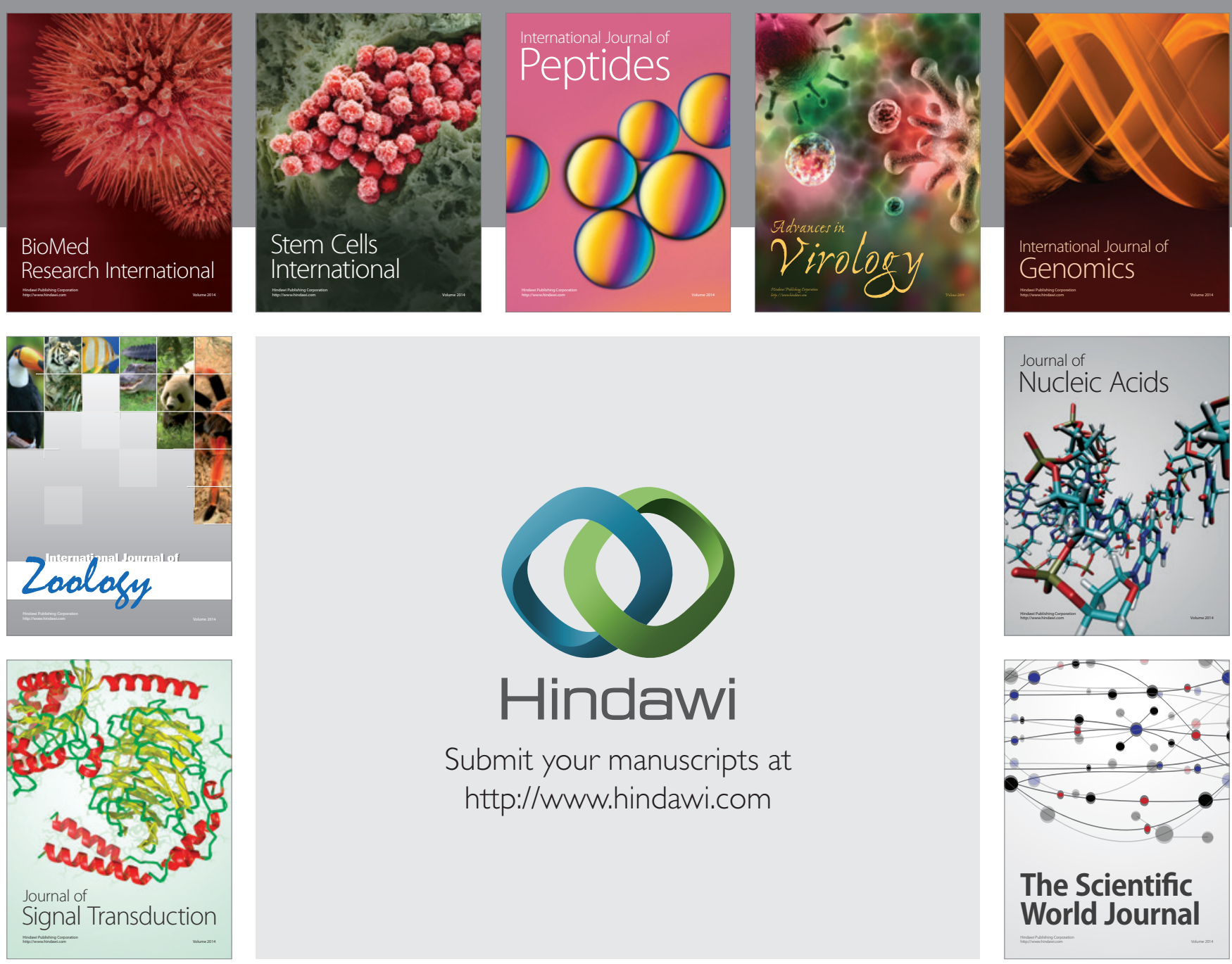

Submit your manuscripts at

http://www.hindawi.com
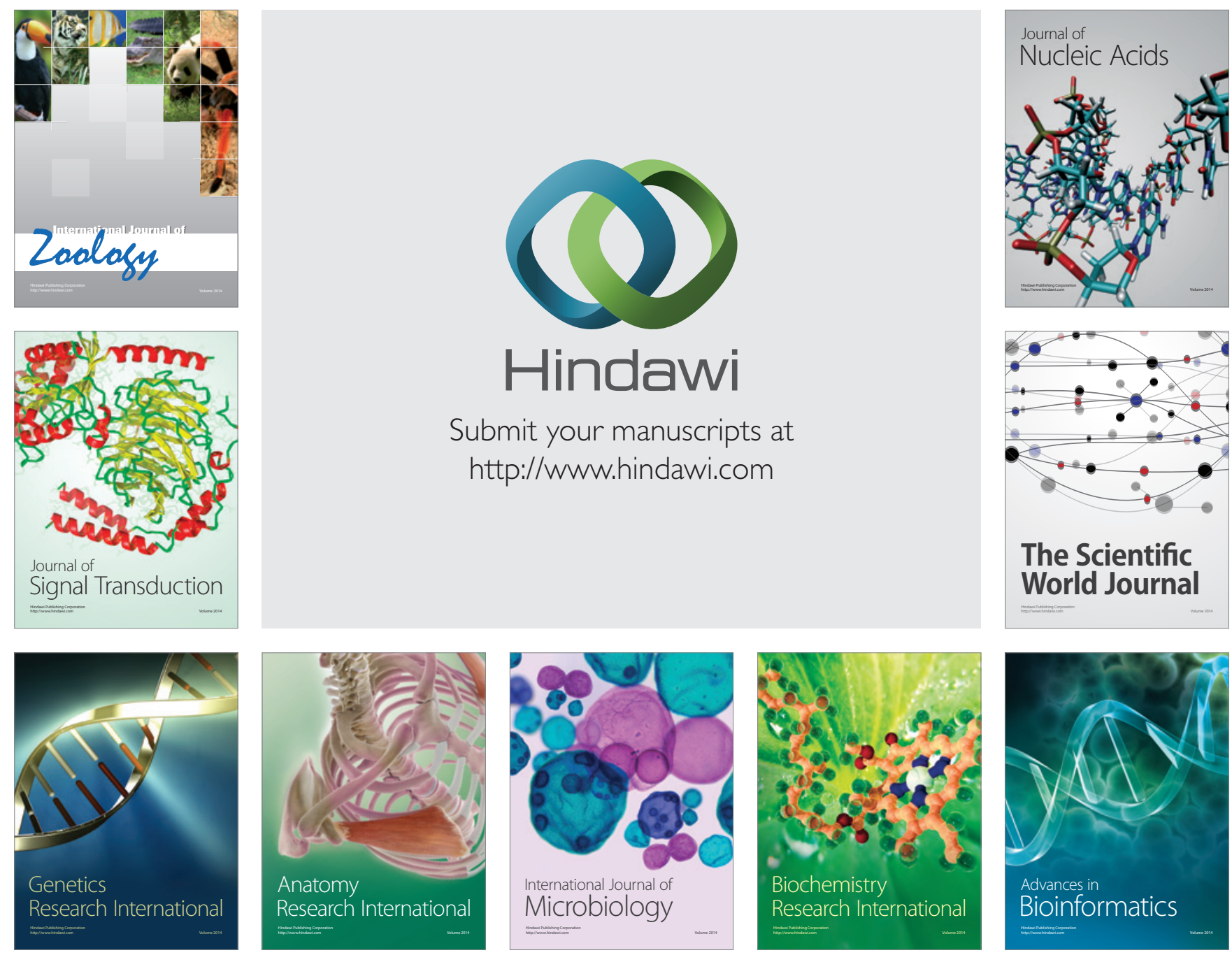

The Scientific World Journal
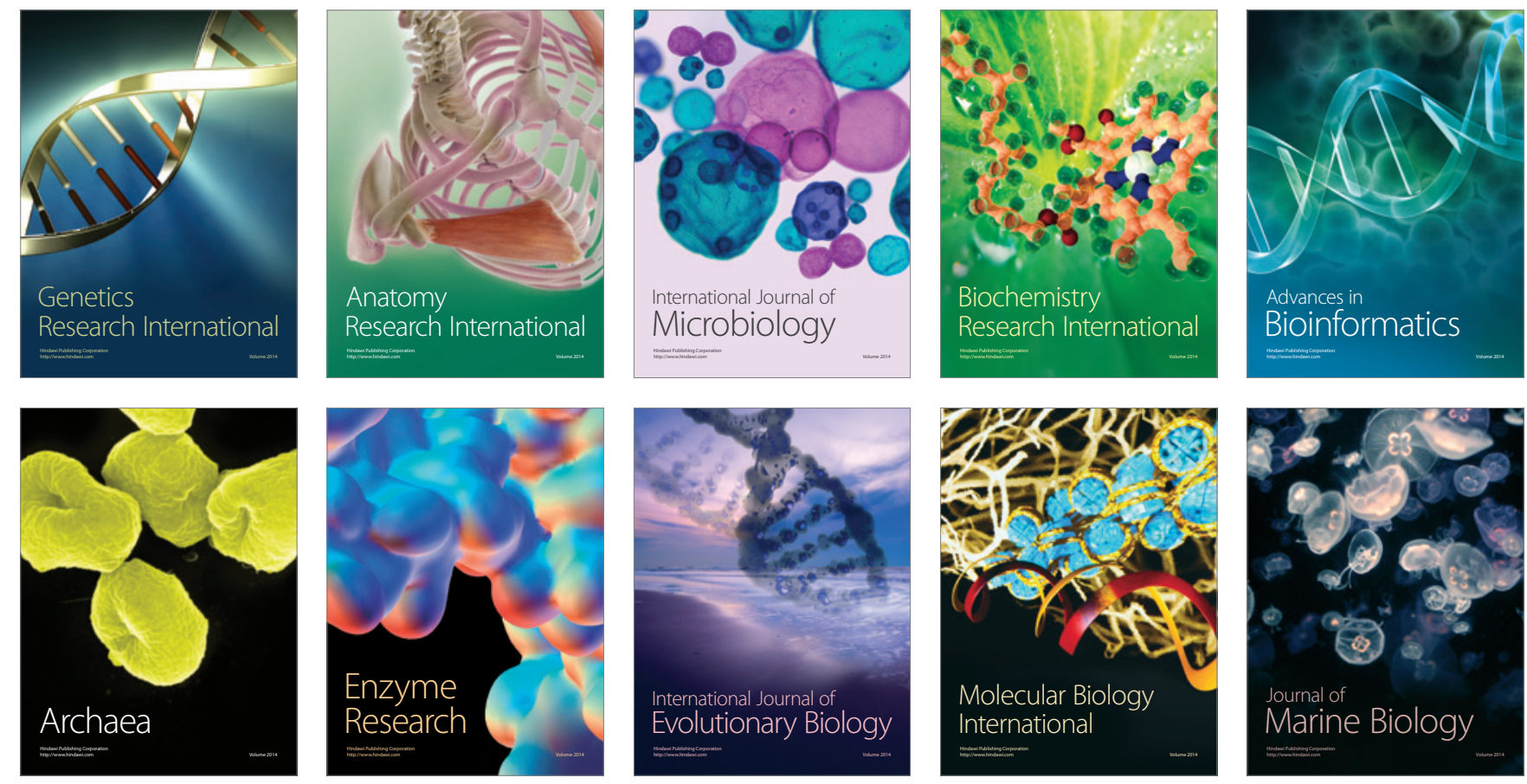